\title{
Parasitic contamination of water sources in Akure, Ondo State, Nigeria
}

\author{
I. A. Simon-Oke* (D) O. J. Afolabi and E. T. Obimakinde
}

\begin{abstract}
Background: Availability of good water source is essential to every community in other to allay the risk of waterborne infection and diseases. In this study, the isolation of parasites and rate of parasitic contamination from different water sources were evaluated in Akure, Nigeria. A total of 816 water samples were collected from wells, streams, boreholes, and rain in the study areas. The samples were examined using calcium carbonate floatation and stained microscopic methods. Also, parameters (temperature, $\mathrm{pH}$, and turbidity) of the different water sources were measured.

Results: Of all the water sources, stream water samples recorded the highest prevalence (45\%), followed by well water (24\%), rain water (21\%), and borehole water having the least prevalence of 10\% with significant difference. Different developmental stages of both protozoan and helminthic parasites were isolated from all the sampled water sources. Protozoa parasites isolated were Cryptosporidium parvum, Gardia spp., and Entamoeba histolytica with prevalence of 33.2, 19.9, and 13.0\% respectively. Dracunculus medinensis and Enterobius vermicularis with prevalence of $10.3 \%$ and 4.0\% respectively were helminthes recovered. It was observed that the occurrence of the parasites in the water sources was affected by the water parameters (temperature, $\mathrm{pH}$, and turbidity). All the water sources harbored at least one parasite except for the borehole water sources in Akure North in which no parasite was isolated.

Conclusion: High parasitic contamination of these water sources imply that water should be treated before consumption to reduce the risk of contracting water-borne disease. Also, government at the local level should provide borehole water system for the communities.
\end{abstract}

Keywords: Water-borne, Parasites, Contamination, Protozoa, Helminths, Akure

\section{Background}

Water is of fundamental importance to human life, animals, and plants. It is of equal importance with the air we breathe in maintaining the vital processes of life, and it makes up $60 \%$ of body weight in human body (Bonjoch, Balleste, \& Blanch, 2004).

Water-borne parasitic infections are considered a threat and of public health importance especially in developing countries (Oyedeji, Olutiola, \& Mononuola, 2010). Water is inevitably the source of life on earth and without it, life sustenance becomes difficult. Water of good quality is of basic importance to human physiology, and man's continued existence depends very much on its availability (Okonko, Ogunnusi, Adejoye, \& Shittu,

* Correspondence: adepejuoke72@gmail.com

Biology Department, Federal University of Technology, Akure, Nigeria
2008). Drinking water could be gotten from sources such as borehole/tap water, well water, dams, rivers, streams, lakes, municipal water, and rain water. Every community of humans, animals, or plants has one or more of these as their source of drinking water. Pollution of groundwater with pathogenic microorganisms is generally believed to be a consequence of migration or introduction of faecal material either from humans or animals into the subsurface. Faecal pollution can reach groundwater from many concentrated pond sources such as cesspools, landfills, leaking sewer lines, and filled septic systems (Sadallah \& Al-Najar, 2014).

Over 3 million deaths per year are attributed to waterborne diarrhoeal diseases especially among infants and young children in poor communities in Africa, Asia, and South America (Anon., 1997). Parasitic infections affect 
work and productivity as they are usually associated with a diminished capacity to carry out physical work (Chollom et al., 2013). Despite the promotion of public health and improvement of life style in the recent years, parasitic diseases have remained a public health problem in many parts of the world. Water is a major source for acquiring several pathogenic agents including bacteria, viruses, and parasites. These biological agents can be transmitted via nonsanitized water (Dura, Kambourova, \& Simeonova, 2006; LV et al., 2013). According to World Health Organization reports, more than 80 infectious diseases can be transmitted by water (Ayaz et al., 2011). Water quality problems and massive contamination remain unsolved leading to transmission of various water-borne diseases.

Therefore, there is a need for continuous research on water quality and sanitation which brought about the isolation and determination of rate of parasitic contamination of different water sources in the study areas. Research of such will provide information on the status of water sources in an environment which will help to reduce the risk of water-borne infections and diseases.

\section{Materials and methods}

\section{Study area}

The study was carried out in Akure (North and South), the capital city of Ondo State, South-Western Nigeria (Fig. 1). It lies between latitude $7^{\circ} 15^{\prime} 0^{\prime \prime} \mathrm{N}$ and longitude $5^{\circ} 11^{\prime} 42^{\prime \prime} \mathrm{E}$. The town is situated in the tropical rainforest zone of Nigeria. The temperature ranges from $25.2{ }^{\circ} \mathrm{C}$ to $28.1{ }^{\circ} \mathrm{C}$ with an average annual rainfall of $2378 \mathrm{~mm}$ and a relative humidity of $80 \%$. It has a population of 588,000 based on 2006 population census, and the populace is made up of mainly Yoruba ethnic group. The major source of water in Akure is subsurface water, and the commonest is well water (Igbekele, 2010).

\section{Study design}

The study was conducted for parasitological evaluation of different water sources which randomly selected in different towns within the study areas. The major towns sampled in Akure North were Iju, Ita-Ogbolu, Igoba, Ogbese, and Oba-Ile while Futa area, Alagbaka, Oja-Oba, Oke Aro, and Aponmu were major areas sampled in Akure South. Sources of sampled water include well water, stored rain water, borehole, and streams. The sites were sampled twice in a month for three consecutive months each for dry season (December, 2017 to February, 2018) and wet seasons (May to July, 2018). The sampled water from the streams was collected from the upper and the lower course of the water body (Iyaji, Lawal, Omowaye, \& Yaro, 2016).

\section{Collection of water samples}

Water samples were collected from wells, streams, boreholes, and rain water in clean bottles. The samples were labeled with dates of collection, nature or source of

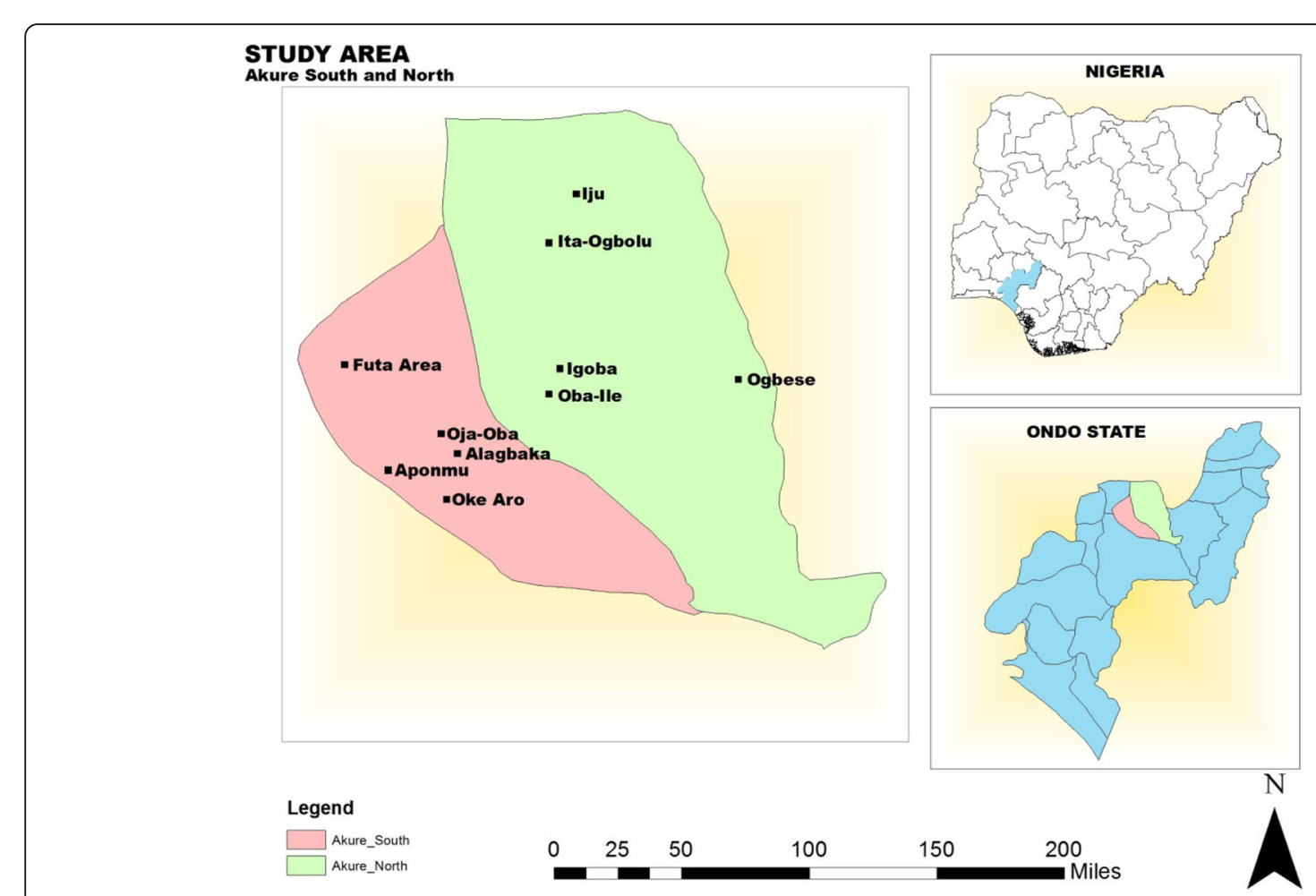

Fig. 1 Map of the sampling sites 
water, the site of collection, and transported to the laboratory of Department of Biology, Federal University of Technology, Akure, for further analysis.

Water parameters measured were temperature (measured with mercury-filled thermometer in ${ }^{\circ} \mathrm{C}$ ), turbidity (measured with secchi disc), and $\mathrm{pH}$ (measured with SETRA pH 25, pH meter).

Capped sample bottles $(100 \mathrm{ml})$ were washed and rinsed with clean warm water, well corked, and properly wrapped with foil paper. The bottles were placed in the autoclave and sterilized for an hour at $121{ }^{\circ} \mathrm{C}$ (Cheesebrough, 2006). After an hour, the bottles were carefully removed from the autoclave and placed in an air-tight and neat plastic bucket and taken to the sample sites for collection. At each sample site, the bottles were careful removed from the bucket one at a time, and water samples were collected into each of the bottles simultaneously.

For samples taken from boreholes, after turning the pump's nozzle on, water was allowed to flow out for $20 \mathrm{~s}$ before collecting the water directly into the bottles as it flows from the water outlet. This was to allow dirt, microbes, or other water contaminants which had previously settled at the base of the tank to flow out before the samples were taken.

For well samples, the water was collected using an already washed neat rubber water fetcher with the bottle bent at an angle of $90^{\circ}$ during each collection to prevent contamination from the environment. After the collection of the water samples, parameters of water, temperature, turbidity, and $\mathrm{pH}$ of the water samples were measured.

\section{Isolation and identification of parasites}

One hundred milliliters of water sample was treated with $1 \mathrm{~g}$ calcium carbonate and left for $2 \mathrm{~h}$ for water particles to settle at the bottom of the bottle. The supernatant was carefully decanted while the sediment was dissolved by adding $1 \mathrm{ml}$ of hydrogen sulphate (iv) acid and allowed to stand for another $2 \mathrm{~h}$. The dissolved sediments were centrifuged at $3000 \mathrm{rpm}$ for $15 \mathrm{~min}$. The supernatant was discarded while the sediments were smeared on grease-free slides (Cheesebrough, 2006).

With the use of pipette, the filtrate was obtained and used to prepare two slides for each sample: one was stained with Lugol's iodine and viewed directly under the microscope (Bakir et al., 2003) while the other was stained with acid fast stain using Ziehl-Neelsons carbol fuchsin stain (FERN; certified suitable for staining acid fast organisms in smears and tissue section) using the cold carbol fuchsin technique. A smear of the sediment was made on grease-free glass slides and was allowed to air-dry for a few minutes, and the smeared slide was fixed with methanol for $3 \mathrm{~min}$ to preserve the parasite on the slide after which the carbol fuchsin was used to stain the slides for $15 \mathrm{~min}$ and rinsed under tap water.
One percent of acid alcohol was used to decolorize the slide for $15 \mathrm{~s}$, and the slides were again rinsed in tap water to remove excess acid alcohol. The slides were counter stained with $0.4 \%$ methylene blue for $60 \mathrm{~s}$ and rinsed under tap water, air dried, and examined under $\times$ 10 and $\times 40$ objective lenses of binocular light microscope (Cheesebrough, 2006). Images of all parasites viewed under the microscope were taken using a digital camera of high resolution power and saved accordingly after which were properly identified using taxonomic keys according to Cheesebrough (2006).

\section{Statistical analysis}

Data were analysed using simple descriptive statistics (chi-square and $t$ test) using the SPSS version $21.0 \mathrm{soft}$ ware. $P$ values less than 0.05 were considered to be statistically significant. All charts were created using Microsoft Excel.

\section{Results}

A total of 816 water samples were collected in the study areas. Four hundred and eight water samples were from both Akure North and South (102 samples from each water sources).

Table 1 shows the prevalence of parasitic contamination in different water sources in the two study areas. It was observed that in Akure North and South, water from the streams had the highest prevalence of 53.9\% and $30.4 \%$ respectively. Water samples from boreholes in the South recorded the lowest prevalence of $18.6 \%$ while in Akure North, there was no parasitic contamination (0\%). Statistical analysis revealed no significant difference in parasitic contamination of water sources $(p>0.05)$.

For the overall prevalence of parasites in all the water sources from Akure North and South, stream water has the highest prevalence of parasites followed by well water, rain water, and borehole water, with the prevalence of $42.2,22.5,19.6$, and $9.3 \%$ respectively with a significant difference $(p<0.05)$.

A total of fourteen (14) parasites with varying developmental stages (egg, oocyst, cyst, and Larva) were isolated. Cryptosporidium parvum, Schistosoma haematobium, Cyclospora cayetanensis, and Strongiloides stercoralis were isolated in the water samples obtained from the two study areas. However, Entamoeba coli, Giardia lamblia, fluke, round worm, Enterobium vermicularis, Dracunculus medinensis, and Naegleria fowleri were isolated from Akure South only, while Entamoeba histolytica, Giardia intestinalis, and Ascaris lumbricoides were isolated from Akure North (Table 2).

Occurrence and prevalence of parasites in different water samples in the study areas are represented in Table 3. Cryptosporidium parvum was observed in all 
Table 1 Prevalence of parasitic contamination in water sources in the study areas

\begin{tabular}{|c|c|c|c|c|c|c|c|c|c|}
\hline \multirow{3}{*}{$\begin{array}{l}\text { Water } \\
\text { sources }\end{array}$} & \multicolumn{6}{|l|}{ Location } & & & \\
\hline & \multicolumn{3}{|l|}{ Akure South } & \multicolumn{3}{|l|}{ Akure North } & \multicolumn{3}{|l|}{ Total } \\
\hline & No examined & No positive & Prevalence (\%) & No examined & No positive & Prevalence (\%) & No examined & No positive & Prevalence (\%) \\
\hline Well & 102 & 20 & 19.6 & 102 & 26 & 25.5 & 204 & 46 & 22.5 \\
\hline Borehole & 102 & 19 & 18.6 & 102 & 0 & 0 & 204 & 19 & 9.3 \\
\hline Stream & 102 & 31 & 30.4 & 102 & 55 & 53.9 & 204 & 86 & 42.2 \\
\hline Rain & 102 & 21 & 20.6 & 102 & 19 & 18.6 & 204 & 40 & 19.6 \\
\hline Total & 408 & 91 & 22.3 & 408 & 111 & 27.2 & 816 & 191 & 23.4 \\
\hline
\end{tabular}

Akure South $(t$ test $=0.061 ; p>0.05)$, Akure North $(t$ test $=0.120 ; p>0.05)$ Total $(t$ test $=0.002 ; p<0.05)$

the water sources sampled with a prevalence of $38.4 \%$ while Cyclospora cayetanensis (1.6\%) was found in well and rain water in the South. In Akure North, Entamoeba histolytica was found in all the water sources except borehole with a total prevalence of 33.6\%, and Strongyloides stercoralis $(0.9 \%)$ was observed in only stream water. Statistical analysis showed significant difference in the occurrence of parasite isolated from well and stream water in the two study areas $(p<0.05)$.

Table 4 shows the seasonal prevalence of parasitic contamination of the different water sources. Result revealed that there was a higher prevalence of contaminants during the wet season $(24.0 \%)$ when compared to the dry season which had a lower prevalence of $22.7 \%$. However, it was observed that samples gotten from streams (46.5\%) and rain water (20.2\%) had higher prevalence of parasites in the dry season when compared to wet season (38.1 and 19.1\%) respectively. Statistical

Table 2 Parasites stages found in different drinking water sources in Akure South and North LGAs

\begin{tabular}{lll}
\hline Parasite & Location & \\
\cline { 2 - 3 } & Akure South & Akure North \\
& Stages & Stages \\
\hline Cryptosporidium parvum & Oocyst & Oocyst \\
Entamoeba coli & Cyst & - \\
Giardia lamblia & Cyst & - \\
Fluke & Egg & - \\
Round worm & Larvae & - \\
Enterobium vermicularis & Larvae & - \\
Schistosoma haematobium & Egg & Egg \\
Cyclospora cayetanensis & Cyst & Cyst \\
Dracunculus medinensis & Larvae & - \\
Strongyloides stercoralis & Larvae & Larvae \\
Naegleria fowleri & Egg & - \\
Entamoeba histolytica & - & Cyst \\
Giardia intestinalis & - & Cyst \\
Ascaris lumbricoides & - & Egg \\
\hline Key: not prest & &
\end{tabular}

Key: not present analysis revealed a significant difference in the seasonal contamination of water samples in both seasons $(p<$ 0.05).

Temperature, $\mathrm{pH}$, and turbidity of the different water sources were measured, and the mean values were expressed (Fig. 2). It was observed that the occurrence of the parasites in the water sources was affected by these parameters. Statistical analysis showed significant difference in the different water parameters $(p<0.05)$

\section{Discussion}

Protozoans and helminths were the main parasites encountered in all the water sources. Cryptosporidium parvum recorded the highest prevalence, and it has been known to be an important water-borne disease causative agent associated with several gastrointestinal diseases in human (Razzolini, da Silva Santos, \& Bastos, 2010). All water sources across the study areas recorded the presence of C. parvum, and this result is in agreement with the findings of Iyaji et al. (2016), who isolated C. parvum in borehole water during their study in Okura District, Kogi State, Nigeria. However, it disagrees with the report of Solomon et al. (2013), who recorded 0\% parasitic contamination in borehole water during their study in Heipang, a rural community in Plateau State, Nigeria.

Entamoeba histolytica, a protozoan parasite known to cause amoebic dysentery in human, was isolated only in Akure North. Giardia spp (G. intestinalis found in Akure North and G. lamblia found in South) recorded the high prevalence. Giardia spp is known to cause giardiasis, a serious gastro intestinal disease. This result is in correlation with the report of Ani and Itiba (2015) who isolated C. Parvum, Giardia spp, and E. histolytica during their study in different sources of drinking water in Abakaliki, Ebonyi State, Nigeria. These three protozoans are known to be part of the major parasites that cause diarrhea (Hernandez \& Avendendo, 2001). Tanyuksel, Tachibana, and Petri (2001) also reported these three parasites to be the most common cause of infection globally. Also, Furness et al. (2000) reported C. parvum and Giardia spp. to induce gastroenteritis and were considered to the leading cause of waterborne diseases in the USA. 


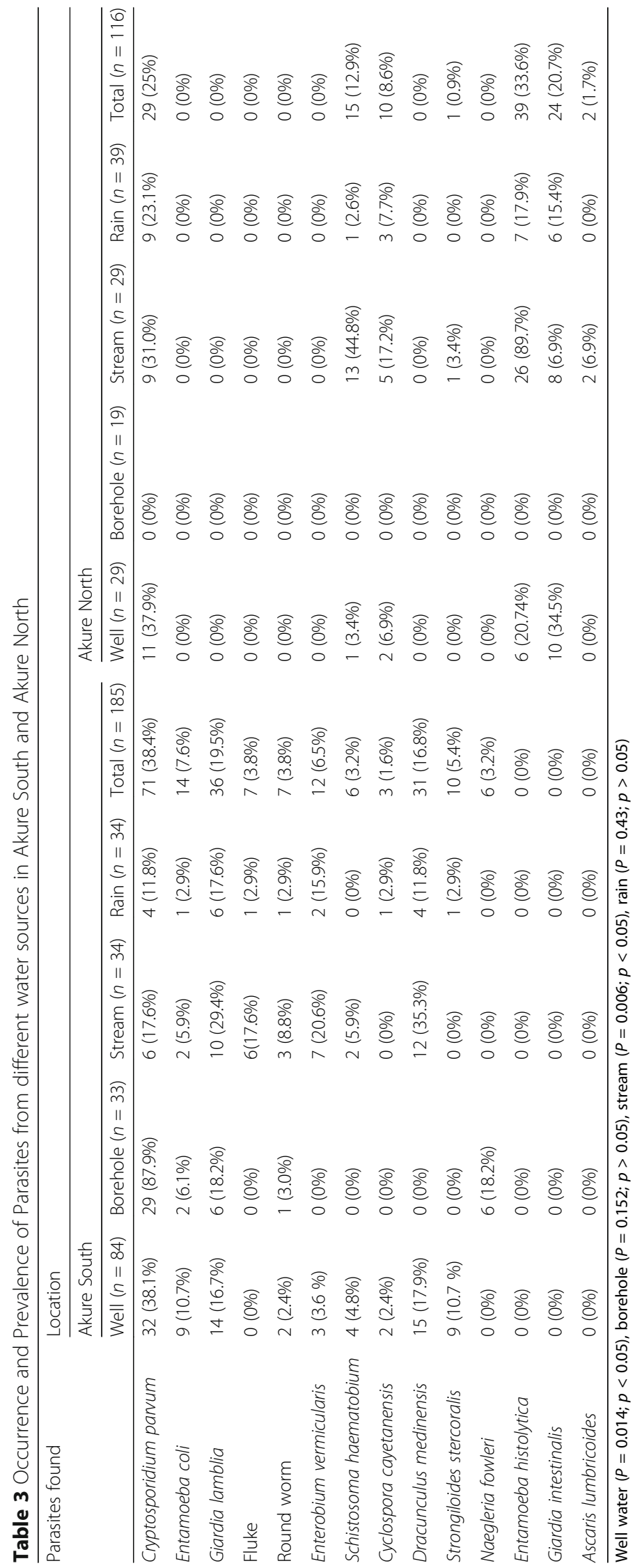


Table 4 Seasonal prevalence parasitic contamination of different water sources

\begin{tabular}{|c|c|c|c|c|c|c|}
\hline \multirow[t]{3}{*}{ Water sources } & \multicolumn{6}{|l|}{ Seasons } \\
\hline & \multicolumn{3}{|l|}{ Dry season } & \multicolumn{3}{|l|}{ Wet season } \\
\hline & No examined & No positive & Prevalence (\%) & No examined & No positive & Prevalence (\% \\
\hline Well & 102 & 18 & 16.7 & 102 & 28 & 27.5 \\
\hline Borehole & 102 & 7 & 6.9 & 102 & 12 & 11.8 \\
\hline Stream & 99 & 46 & 46.5 & 105 & 40 & 38.1 \\
\hline Rain & 84 & 17 & 20.2 & 120 & 23 & 19.2 \\
\hline Total & 387 & 88 & 22.7 & 429 & 103 & 24.0 \\
\hline
\end{tabular}

Dry season $\left(x^{2}=48.159, \mathrm{df}=3, P=0.001\right)$, wet season $\left(x^{2}=22.005, \mathrm{df}=3, P=0.001\right)(P<0.05)$

Among the helminthes that were isolated from the different water sources, Dracunculu medinensis and Enterobius vermicularis recorded the high prevalence, although the two parasites were found in Akure South only. However, a high prevalence (12.9\%) of Schistosoma haematobium was recorded in Akure North compared to South (3.2\%). Also, it was observed that Ascaris lumbricoides was found in Akure North but absent in the South. The presence of these helminthic parasites in the study area is in conformity with previous reports of other researchers. For instance, Solomon et al. (2013) who worked in a rural community in Nigeria, Ani and Itiba (2015) who worked in Abakaliki, Ebonyi State, Nigeria, and Iyaji et al. (2016) who worked in Okura District, Dekina Local Government, Kogi State, Nigeria, all in their studies, isolated helminthes in the different water samples which they studied. Results obtained from this study indicate that people residing in the study area who depend on all the sources of water are at great risk of contracting water-borne diseases if they fail to treat the water before use. However, residents within Akure
North who depend on boreholes as source of water might be at lesser risk of contracting water-borne diseases due to the fact that the all borehole water sources examined in this region were void of parasites.

Of the water sources, stream water has the highest prevalence of parasitic contamination, followed by well water, rain water, and borehole having the lowest prevalence. It was observed that all sampled boreholes in Akure North have no parasitic contamination. The result obtained from Akure North is in agreement with the report of Solomon et al. (2013) who isolated parasites of varying developmental stages in all the water sources they sampled except from boreholes which yielded $0 \%$ prevalence. However, it is dissimilar from the report of Ani and Itiba (2015) and Iyaji et al. (2016) who in their respective research isolated parasites from all the water sources they examined including boreholes.

The wet season recorded higher prevalence of parasitic contamination when compared with the dry season. This observation is in line with the result obtained by Pam et al. (2018) in their research at Doma local government
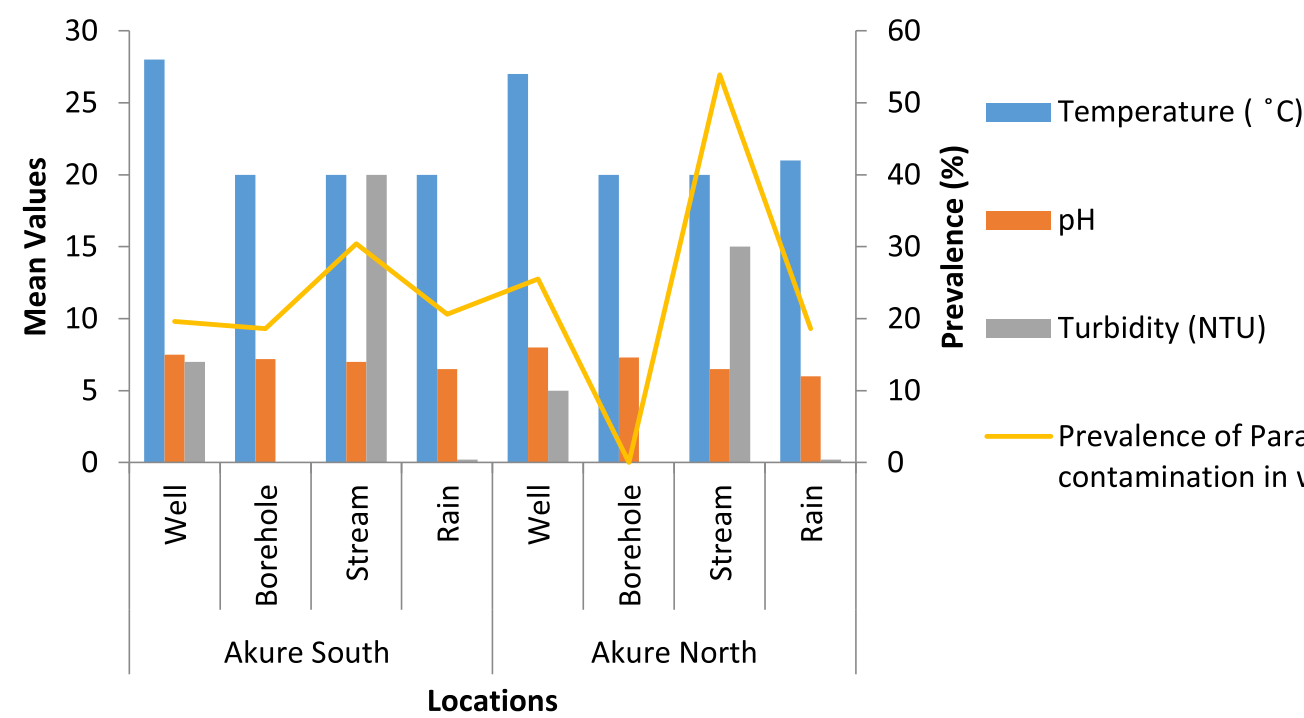

- Prevalence of Parasitic contamination in water sources

Fig. 2 Water parameters in relation to the occurrence of parasite in water sources. Statistical analysis showed significant difference in the different water parameters $(p<0.05)$ 
area of Nasarawa State, Nigeria, who recorded a higher overall prevalence of $59.38 \%$ of parasitic contamination in different water sources during the wet season to a lower overall prevalence of $40.63 \%$ during the dry season. Also, they recorded the highest prevalence of contamination in stream samples during both dry and wet season (69.23and $94.74 \%$ respectively). The reason for the stream having the highest prevalence could be as a result of human activities such as indiscriminate dumping of waste and defecation into the water body.

Relating the measured water parameters with the abundance of parasites in the water sources, it was observed that stream water which had the highest parasite contamination has a very high turbidity, a moderate $\mathrm{pH}$. and suitable temperature for parasite survival while rain water has low turbidity, slightly low $\mathrm{pH}$. and lower temperature. Rain water is slightly acidic because there is interference of the rain water with $\mathrm{CO} 2$ in the atmosphere. Living organisms survive more at neutral to slightly alkaline $\mathrm{pH}$ (Odikamnoro, Omowaye, \& Uduituma, 2014).

Generally, the presence of different parasites in the various water sources in the study area could be as a result of poor hygiene on people residing in the study area. People defecating close to the stream might have contributed to the contamination of this water source. During fetching of water from wells, the use of unclean contaminated materials might have led to the contamination well water. Leaving wells uncovered after use could have also exposed the well to parasitic contaminants. Stored rain water might also have gotten contaminated though the use of unclean materials and dirty hands dipped into the storage containers. Agricultural activities such as use of manure in which erosion could have washed some parasitic contaminants present in manures into the stream might have been another means through which the stream got contaminated. In some of the streams sampled, S. haematobium was isolated; the presence of this parasite could have been as a result of the presence of snail intermediate host in the water body and people engaging in different activities in the stream, and this facilitates the completion of the parasites life cycle. An infected individual urinating into the stream could have also been a source of contamination.

\section{Conclusion}

From the results obtained from this research, it is apparent that the sampled water sources were contaminated with parasites which indicate that residents in the study areas are at great risk of contracting water-borne parasitic diseases; therefore, it is imperative that water sources in this region should be treated before consumption in other which allays the risk of infection. Also, borehole water sources presented a low prevalence of contamination which could be attributed to the depth, and the engineering work which limits debris and parasites accessibility. Hence, the use of boreholes as source of water should be encouraged. Government should provide borehole water system in every part of study areas which will drastically reduce the chance of contracting water-borne diseases.

\section{Acknowledgements \\ Authors appreciate the effort of Mrs. E. T. Ojo (Chief Technologist, Biology \\ Department, Federal University of Technology, Akure) for her effort and \\ support during the laboratory work of this research.}

\section{Authors' contributions}

This research work was carried out by all the authors. Author IAS designed the study, IAS and OJA performed the statistical analysis, write the protocol and the first draft. Authors IAS, OJA and ETO managed the analyses and literature searches. All authors read and approved the final manuscript.

\section{Funding}

Not applicable

\section{Availability of data and materials}

Please contact author for data requests.

Ethics approval and consent to participate

The research does not involve collection of samples from human or animal subjects. Advocate visits were paid to the kings and high chiefs of the selected towns and villages to intimate them on the research and to obtain permission.

\section{Consent for publication}

Not applicable

\section{Competing interests}

The authors declare that there is no competing interest.

Received: 30 May 2019 Accepted: 13 July 2020

Published online: 29 July 2020

\section{References}

Ani, O. C., \& Itiba, O. L. (2015). Evaluation of the parasitic contamination of local sources of drinking water in Abakaliki, Ebonyi State, Nigeria. Journal of Dental and Medical Sciences, 14(9), 30-34.

Anon. (1997). World Health Report. World Health Forum, 97, 181-188.

Ayaz, S., Khan, S., Khan, S. N., Bibi, F., Shamas, S., \& Akhtar, M. (2011). Prevalence of zoonotic parasites in drinking water of three districts of Khyber Pakhtunkhwa Province, Pakistan. Pakistan J Life Soc Sci., 9(1), 67-69.

Bakir, B., Tanyuksel, M., Saylam, F., Tanriverdis, S., Araz, R. E., Hacim, A. K., \& Hasde, M. (2003). Investigation of waterborne parasites in drinking water sources of Ankara, Turkey. Journal of Microbiology, 41(2), 148-151.

Bonjoch, X., Balleste, E., \& Blanch, A. R. (2004). Multiplex PCR with 165 RNA genetargeted primers of Bifido-bacterium spp to identify sources of fecal pollution in water. Applied Environmental Microbiology, 70, 3171-3175.

Cheesebrough, M. (2006). District laboratory practice in the tropical countries, (2nd ed., pp. 39-157). Cambridge, UK: Cambridge University Press.

Chollom, S. C., Iduh, M. U., Gyang, B. J., idoko, M. A., Ujah, A., Agada, G. O., Okwori, J. A. (2013). Parasitological evaluation of domestic water sources in a rural community in Nigeria. British Microbiology Research Journal, 3(3), 393-399.

Dura G, Kambourova V, Simeonova F, (2006). NATO Programme for Security through Science, Management of Intentional and Accidental Water Pollution: Springer;

Furness, B., Beach, M., \& Roberts, J. (2000). Giardiasis Surveillance in United States, Morbidity and Mortality. Weekly Report, 49, 1-3.

Hernandez, C. F., \& Avendendo, L. (2001). Simple Modification of the Baermann method for diagnosis of strongyloidiasis. Mem Inst. Oswaldo Cruz, Rio de Janeiro., 96, 805-807. 
Igbekele, A., (2010). Akure City profile.International water management institute. Available at: http://www.google.com.ng/search?hl = en

Iyaji, F. O., Lawal, A., Omowaye, O. S., \& Yaro, C. A. (2016). Evaluation of parasites of medical importance in drinking water sources in Okura District, Dekina Local Government, Kogi State, Nigeria. International Journal of Development Research, 6(4), 7290-7294.

Lv, S., Tian, L. G., Liu, Q., Qian, M. B., Fu, Q., Steinmann, P., et al. (2013). Water-related parasitic diseases in China. Int J Environ Res Public Health, 10(5), 1977-2016.

Odikamnoro, O. O., Omowaye, O. S., \& Uduituma, S. O. (2014). Parasitic survey of drinking water sources in Ohaukwu Local Government Area, Ebonyi State, Nigeria. European Journal of Nursing, 1(1), 1-5.

Okonko, I. O., Ogunnusi, T. A., Adejoye, O. D., \& Shittu, O. B. (2008). Microbiological and physicochemical analysis of different water samples use for domestic purposes in Abeokuta, Ogun State and Ojota, Lagos State, Nigeria. African Journal of Biotechnology, 7(5), 617-621.

Oyedeji, O., Olutiola, P. O., \& Mononuola, M. A. (2010). Microbiological quality of packaged drinking water brands marketed in Ibadan metropolis and lle-lle city in South Western Nigeria. Journal of Microbiology Research, 4(1), 96-102.

Pam, V. A., Ombugadu, A., Adejoh, V. A., Idris, A. A., Pam, D. D., Rwang, P. G., Dogo, S. K. (2018). Evaluation of parasitic contamination of local potable water sources in Doma local government Area of Nasarawa State, Nigeria. Tropical Freshwater Biology, 27(2), 31-34.

Razzolini, M. T. P., da Silva Santos, T. F., \& Bastos, V. K. (2010). Detection of Giardia and Cryptosporidium cysts/oocysts in watersheds and drinking water sources in Brazil urban areas. Journal of water and health, 8(2), 399-404.

Sadallah, H., \& Al-Najar, H. (2014). Effectiveness of water supply disinfection system in Um Al-Nasser village as a marginal rural community. M Sc Thesis: University of Gaza.

Solomon, C. C., Michael, U. I., Bitrus, J. G., Micheal, A. I., Aloysius, U., Godwin, O. A., Joseph, A. O. (2013). Parasitological evaluation of domestic water sources in a rural community in Nigeria. British Microbiology Research Journal, 3(3), 393-399.

Tanyuksel, M., Tachibana, H., \& Petri, W. A. (2001). Amebiasis, an Emerging Disease; 212.

\section{Publisher's Note}

Springer Nature remains neutral with regard to jurisdictional claims in published maps and institutional affiliations.

\section{Submit your manuscript to a SpringerOpen ${ }^{\circ}$ journal and benefit from:}

- Convenient online submission

- Rigorous peer review

- Open access: articles freely available online

High visibility within the field

- Retaining the copyright to your article

Submit your next manuscript at $\boldsymbol{\nabla}$ springeropen.com 